\title{
Lesson Study Matters in Ireland
}

\author{
Kathryn McSweeney ${ }^{1} \mathrm{PhD}$; John Gardner ${ }^{2} \mathrm{PhD}$ \\ St. Angela's College, Ireland ${ }^{1}$; University of Stirling, United Kingdom ${ }^{2}$ \\ kmcsweeney@stangelas.nuigalway.ie ${ }^{1}$; john.gardner@ stir.ac.uk ${ }^{2}$
}

\begin{abstract}
Lesson Study is an approach to improving classroom teaching that focuses on collaborative professional learning between teachers. This paper reports on Lesson Study developments in Ireland, its use in two schools, one in Northern Ireland and one in the Republic of Ireland, and in particular its use in Home Economics education. The aim of the project was to assess the potential for Lesson Study to improve classroom pedagogy in selected areas of the schools' provision. The schools identified three challenging aspects for study: improvement of literacy levels, use of Assessment for learning-type pedagogy and use of innovative teaching methods to enhance learning in Home Economics. The teachers considered that the Lesson Study approach contributed to improved pedagogy and student outcomes in their chosen areas. This was accomplished through collaborative professional learning, meaningful dialogue between the teachers about pedagogy and student learning, deeper levels of reflection by the teachers and profound changes in the teachers' understanding and learning about practice.
\end{abstract}

Keywords: Lesson Study, professional learning, life-long learning, adult education.

\section{Introduction}

The context for teaching today is dynamic and evolving and the accelerated pace of societal change, legislative and educational reform requires that teachers are prepared for life-long learning as they face a range of new challenges and opportunities in the classroom. Within this arena, Lesson Study has emerged as an innovative alternative to conventional methods of promoting professional learning. This paper reports on how two schools successfully implemented and evaluated Lesson Study in aspects of their teaching. The study aimed to determine the effectiveness of Lesson Study as a school based and peer-to-peer approach to teacher professional development.

The most common form of lifelong learning in the professions is continuing professional development (CPD), described by C. Day and J. Sachs in the context of teaching as "a term used to describe all the activities in which teachers engage during the course of a career, which are designed to enhance their work" (Day, Sachs, 2004, 3). The OECD Teaching and Learning International Survey (TALIS) report broadly defines professional development as 'activities that aim to advance teachers' skills and knowledge, with the ultimate aim of improving their teaching practice' (OECD, 2014, 87). There are, of course, different modes of professional development and D. Galanouli (2010) has reviewed these. The author argues that the key features of successful professional development include engaging the teachers in collaborative enquiry, ensuring the support of school leaders and involving all stakeholders in the process. She identifies the teachers' active involvement in their own professional development as a key to success.

There is widespread recognition amongst schools' senior management teams of the fact that the spirit of Lesson Study is contrary to the usual top-down model of professional development. S. Mitchell considers that this latter model can often result in "professional indigestion" (Gardner et al., 2012, 20), where ideas and concepts are communicated, but with little time for absorption, consolidation, or application. M. Dadds (1997) explains that a delivery model of CPD does not take cognisance of the "complexity of processes which teachers undergo as they continue to learn about their professional craft; as they continue to gain new knowledge and understanding; reconstruct their attitudes, beliefs, practices; struggle with the difficulties of the change process" (Dadds, 1997, 32). Many, in her view, "come with a convincing feeling that what is inside them is not valid because it is "only personal" to them. Somewhere along the line ... they have learnt to seek the "expert" outside but deny that there may be a potential "expert" within" (Dadds, 1997, 33). She argues that teachers do not enter into their professional development as 'empty vessels' as they bring with them varying levels of experience and expertise, preconceptions and beliefs about teaching and learning and insights, all of which are "useful resources which can be drawn upon and studied in CPD processes" (Dadds, 1997, 32).

Teachers' professional development is not only a concern of teachers and schools. A recent European Commission working document on Competences for the 21 ${ }^{\text {st }}$ Century: An Agenda for European Cooperation on Schools (Commission of the European..., 2008), has presented empirical evidence of 
stakeholders' views regarding present and future school education. Some major trends emerged from the consultation and one aspect related to teachers' professional development. The report emphasizes the importance of presenting teaching as "a problem-solving or research-in-action activity during which teaching methods and strategies, formal or informal, are examined in relation to the children's learning" (Commission of the European..., 2008, 5). The need to improve the quality of in-service training is recognised in addition to the need to provide resources and time for such practice. One aim of the OECD TALIS research studies was to determine the level and quality of professional development amongst lower secondary teachers in 24 countries including Ireland during the period 2007-2008 (OECD, 2009) and in 34 countries during 2012-2013 (OECD, 2014), not including Ireland in this case. The reports conclude that better support for teachers was required, for example, professional development opportunities, incentives for participation and scheduled time for professional development activities during the school day. Whilst participation in teacher professional development in Ireland was ranked as average in the 2009 report, it is interesting to note that the intensity of participation was ranked as low in comparison to other countries (OECD, 2014, 54). Although not covered in the 2014 report, this situation is unlikely to have changed significantly in Ireland given that there has been no major initiative to address the issue since 2009.

A second analysis of the OECD (OECD, 2009) report was published in Teachers' Professional Development: Europe in international comparison (Scheerens, 2010). The report emphasises two dimensions of professional development. The first focuses on the development of thoughtful reflection on teachers' everyday practice and the second on the improvement of teacher quality and the enhancement of student achievement. The report supports the integration of professional development in everyday practice and asserts that research evidence on teacher effectiveness "underlines the importance of overall teaching quality as a lever for improving student achievement" (Scheerens, 2010, 190). Teachers' roles in secondary processes of research, innovation and leadership are promoted as part of the modernisation of the teaching profession. This view is further consolidated in the 2012 European Commission Report Education: Policy Support for Teacher Educators which argues that "in a context of increasing professionalisation, teachers have a responsibility to extend the boundaries of professional knowledge through a commitment to reflective practice, research, and systematic engagement in professional learning throughout their careers" (European Commission, 2012, 1).

The Teaching Council of Ireland (Policy on the Continuum..., 2011) argues that effective professional development should enable teachers to develop their capacity to evaluate pedagogical beliefs and practices, to engage in critical reflection and professional collaboration. D. Galanouli (2010) describes Lesson Study as offering these types of activity, judging it to be a true bottom-up model of professional development where teachers are directly involved in the design, planning and implementation of the professional development activity. J. Stigler and J. Hiebert summed up the essential driver for lesson study initiatives when they wrote that 'if you want to improve teaching, the most effective place to do so is in the context of the classroom' (Stigler, Hiebert, 1999, 111).

\section{What is Lesson Study?}

Lesson Study is a form of teacher professional development and professional learning involving pedagogic improvement brought about by collaborative cycles of lesson design, implementation and review. Lesson Study is associated with the involvement of teams of teachers in collaborative research on classroom lessons in vivo. Interestingly, the term 'research lesson' is frequently used in the literature (Lewis, Perry, Murata, 2006; Lewis, 2009) to indicate the application of a research approach to classroom lessons. The key stages of identifying the focus for a lesson study, planning its development, implementing the plan and evaluating the lesson feature in many models of Lesson Study. These are represented schematically in Figure 1.

In a typical example of a Lesson Study cycle as set out in stage 1 of Figure 1, Identification, a group of teachers form a 'learning community' to examine and identify a challenging area of teaching. This process is central to Lesson Study as it initiates the central plank of the approach: a collegial identification of a shared practice that may previously have been something each teacher tackled unilaterally. It features in all models of Lesson Study including, for example, C.C. Lewis, R. Perry and A. Murata's four stage model (Lewis, Perry, Murata, 2006), in which they describe an initial process of studying the curriculum and formulating a goal. Examples of the focus for lessons might include challenges around such topics as the 
development of problem solving and creativity. Lesson Study specifically tries to ensure that students have an input and the roles they will play are identified. Most importantly, this first stage identifies the ground rules for proceeding, for example in establishing a working environment characterised by trust, respect, confidentiality, freedom to take risks and constructive criticism.

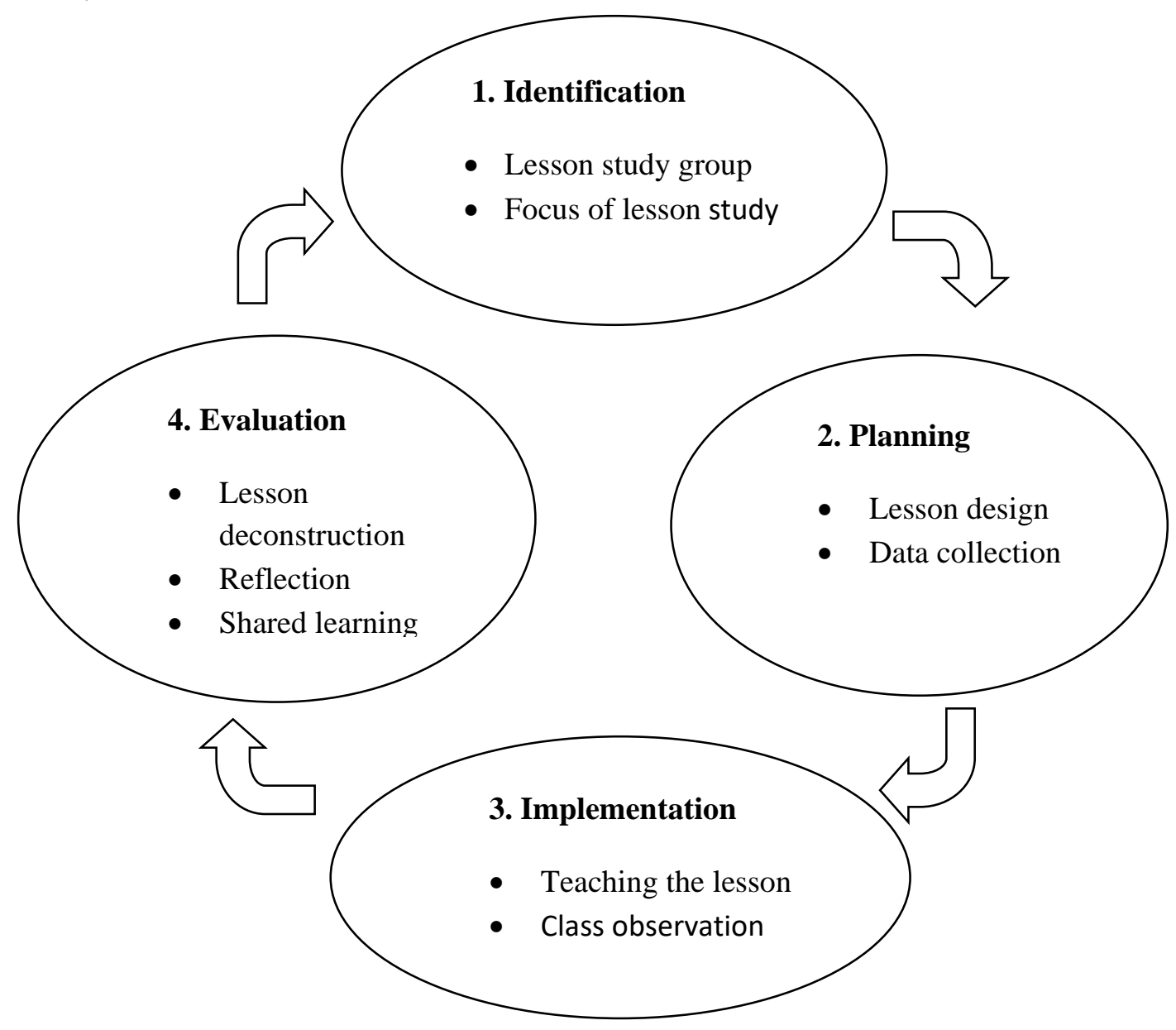

Figure 1. The Lesson Study Cycle.

In stage 2, Planning, the group of teachers then collaborate on the planning and design of a lesson that intends to address the student learning challenges through new approaches to the teaching and the engagement of a student viewpoint. In stage 3, Implementation, the lesson is taught (effectively trialled) by one teacher while the others observe and collect data for later analysis, including, for example, the reactions of students to the teaching. In stage 4, Evaluation, the group meet after the lesson to discuss how the lesson achieved or did not achieve the desired learning outcomes for the students. In a form of an action research cycle, the findings are used to improve the lesson for subsequent delivery by another member of the group and the reflective cycle of plan, implement and refine is repeated as often as is necessary (or possible) with the aim of having a demonstrably effective lesson for the identified challenge. One lesson does not, of course, solve every teaching challenge and the process of reflection must be in-depth. A typical team may therefore engage in only two or three cycles on specific issues over the course of an academic year, but the aim remains the same whatever the duration, i.e. to provide the means of addressing difficult challenges over time through collegial effort.

The ideal outcome from Lesson Study approaches is that the processes of collaboration, observation and sharing of experiences on identified teaching challenges becomes second nature as each teacher, or group of teachers, and ultimately the whole school, adopt the philosophy of shared planning and experimentation. Its key features are: experimenting with teaching techniques, development of shared knowledge and experience about what works (and does not work), valuing students' inputs to the lesson design processes and self and collective reflection. 


\section{Lesson Study Legacy}

Lesson Study has a long-documented history in Japan as a method of teacher professional development and the term 'Lesson Study' is in fact a literal translation of the Japanese word 'Jugyokenkyu' (Fernandez, 2002). C.C. Lewis (2010) reports that in Japan, practitioners and researchers engage in collaborative Lesson Study firstly at a local level (perhaps in a school, or within a cluster of schools) and these 'research lessons' may then be provided either in publically accessible live or video captured sessions, which contribute to the wider sharing of standards. The author argues that much of the knowledge for teaching is embodied in the instruction itself and is spread and refined as teachers watch each other teach rather than through the medium of written documents. These public lessons, which may be live in conference settings, or recorded and streamed for wider consumption, spark purposeful conversations about learning among practitioners, researchers and policy makers. The practice is gathering pace in other countries and, for example in the United Kingdom context, empirical evidence from D. Burghes and D. Robinson (2009) and P. Dudley (2008) strongly points to the effectiveness of Lesson Study in contributing to school improvement. The method has been adopted across all content areas and most notably in Mathematics and Science. Lesson Study has been associated with the improvement of classroom pedagogy and the professional development of teachers by such writers as J.W. Stigler and J. Hiebert (1999), who linked the 1999 Trends in International Mathematics and Science Study (TIMSS) success in Mathematics in Japanese schools to the regular and long-term use of Lesson Study by Japanese teachers. A variety of writers such as C. Fernandez and M. Yoshida (2004), W. Cerbin and B. Kopp (2006), C.C. Lewis, R. Perry and A. Murata (2006) and C.C. Lewis (2009) have added to the research base, mostly in the area of Mathematics education in the United States with strong endorsement of the inherent capacity of Lesson Study to enhance classroom pedagogy and student learning.

Lesson Study has been included in initial teacher education Mathematics programmes at primary and post-primary level and introduced at school-based level in the RoI in recent years (Brosnan, 2007; Corcoran, 2007; Corcoran, Pepperell, 2011; Leavy, Hourigan, 2016; Ni Shuilleabhain, 2016). The increased use of Lesson Study in the specific context of Mathematics began in a wide range of Irish post-primary schools with the launch of a revised Mathematics curriculum entitled 'Project Maths' in 2008 (DES, 2010). This programme aims to enhance students' learning experience, achievement, and understanding and application of mathematical concepts. A recent comparative educational study by A. Ni Shuilleabhain and S. Clivaz (2017) focused on the role of Lesson Study in the explication and development of teacher knowledge. Lesson Study in a Home Economics educational context is becoming more familiar and used. N. Kishi, N. Arai and other Japanese scientists (Kishi et al., 2017) evaluated different types of Lesson Study in Home Economics education. The important role of national and local organisations in the development of Lesson Study research and professional training for teachers was acknowledged in their study. Long-term collaborations are developed which in turn provide opportunities for "spiral research studies" (Kishi et al., 2017, 96). Outside of Mathematics, the study reported here is one of a very small number on Lesson Study in Ireland and in particular on Lesson Study in Home Economics education.

\section{Methodology}

The project aimed to determine the effectiveness of Lesson Study as a school based and peer-to-peer approach to teacher professional development. Two second-level schools, one located in Northern Ireland (NI) and the other located in the Republic of Ireland (RoI), took part in the study. Stage 1 of the Lesson Study cycle, Identification, (Figure 1) involved the researchers and schools in identifying the teams in each school and the area of practice to be studied. Two groups of three teachers $(n=6)$ in the NI school chose the use of Assessment for Learning-type pedagogy (in Drama, History and Sociology), and literacy development (in Science, English and Geography) respectively, whilst one group of three teachers in the RoI school $(n=3)$ chose a focus on helping students to grasp difficult aspects of microbiology in the Home Economics curriculum. The NI school groups worked 'vertically' with classes in years 8-11 (11-13 years) and the RoI school worked 'horizontally' across final year Home Economics classes (17-18 years).

The second stage of the Lesson Study cycle, Planning, involved the groups in formulating their 'research lesson' plans. The research team also used this phase to familiarise the teachers with the various data 
collection methods and instruments such as specially formulated templates for recording student reactions to the teaching and a record of the teachers' observations to guide post-lesson dialogue. During this phase, the main data collection processes were designed, including protocols for involving student observers (students who would comment on the lesson afterwards) and for identifying students who were known to have difficulties in the matters being taught. The reaction of these students formed one focus for the observing teachers in gathering data. Teaching the research lesson formed the third stage of the cycle, the Implementation, and involved live observation and recording of data by the research team. This was followed by a comprehensive evaluation (stage 4) involving lesson deconstruction, reflection and sharing of learning that informed the improvement of the lesson for future practice. Both schools sought to substantiate their findings by inviting selected students to provide their views about the effectiveness of the classroom pedagogy used during the research lessons.

Data collection and analysis were ongoing processes with periodic meetings between the researchers and the researching teachers. It was an important feature of the project that the teachers were also considered to be researchers, primarily in an action research mode but also as critical evaluators of the data. The first stage of data collection was a baseline interview with each teacher on a one-to-one basis, designed to capture aspects of their current approaches to professional development and the extent if any of their existing engagement of students in planning and evaluating lessons. Comprehensive data collection instruments were co-designed for capturing planning decisions, observations, student reactions and data from post-lesson discussions including focus groups with the selected student evaluators. Video capture of the lessons enabled the researchers and teachers to evaluate and revisit rich records of the lesson processes. The final stages of the project involved one-to-one interviews with the teachers as a follow through for the initial baseline interviews.

The data analysis involved reducing large volumes of qualitative data (including extensive narrative, interview and video data) to manageable levels that could enable meaningful findings to be identified. This was accomplished firstly through a process of collating the various perceptions of the teachers (from interviews and narrative records of meetings, observations) under a set of main themes including the effectiveness of Lesson Study as a peer-to-peer professional development approach, a comparison of Lesson Study to other forms of professional development experienced by the teachers, the perceived impact on student learning, the perceived impact on classroom practice, being observed by colleagues, being an observer, involving students in lesson evaluation, the effectiveness of Lesson Study in promoting self-evaluation and developing a team approach. A parallel pursuit was the identification of any perceived limitations of the Lesson Study approach. Once the findings had been refined through discussions within the researcher team, they were tested for validity with the teachers themselves. The Findings section below provides an overview of the collected data under the headings: Lesson Study effectiveness in professional learning, Lesson Study impact on classroom practice and a critique of the Lesson Study approach

\section{Results and Discussion}

\section{Lesson Study effectiveness in professional learning}

All of the teachers viewed the Lesson Study process as an enriching and beneficial experience and identified aspects that were of value to them professionally. They felt that the dual role as researchers and change agents in a typical action research cycle had broadened their perspectives and knowledge in terms of practice, self-efficacy, critical thinking and 'reflection-in-action'; qualities which A. Lauriala (2011) associates with good pedagogy.

The sharing of good practice was viewed overall by the teachers as enriching and inspiring and in the case of the NI school, they expressed the view that for the first time, they were able to observe how students learn across subjects. One of the Home Economics teachers in the RoI school reported that the project provided 'an opportunity to share expertise and resources and to bounce ideas off one another.' The Lesson Study method was considered effective due to the peer-to-peer, collaborative approach adopted. The collegial process was viewed by all as beneficial and enjoyable, as illustrated by a comment from an NI school teacher: "through this project we have been afforded the time to "connect" with our colleagues and to make valuable links with colleagues from other departments.' An important finding from the NI schools was the positive effect of meaningful reflection and discussions among teachers from different subject areas on student learning and the observation of students' learning across a range 
of subjects. Before the project, the teachers did not have exposure to how students learn across subjects and one of them stated that:

'I believe undoubtedly this is the way forward in terms of self-evaluation, learning and teaching as I have been given the opportunity to plan, prepare, observe and evaluate alongside teachers who are from different departments and who are at different stages of their teaching careers than me.'

Some teachers articulated the value of group planning and discussions to their own practice and they would have liked more time for collaborative work. Traditionally, the norm had been an individual rather than a cooperative approach to professional practice. The expression of the positive support experienced by the teachers was an interesting development with one teacher declaring: 'I felt secure and supported within my team.' Another teacher reported: 'I have been inspired by certain strategies that my colleagues employ in their classrooms, so this has allowed me the opportunity to learn from fellow professionals and continue to develop and grow'.

Reflective practice has been widely recognised as an essential teaching quality. The General Teaching Council for Northen Ireland (GTCNI) outlined the value of reflective practice and action research in their document Teaching: The Reflective Profession. They stated that teachers 'can develop new understandings of learning, teaching and educational change' (Teaching: the Reflective..., 2007, 9) through reflective practice. The observations and lesson deconstructions that take place as part of a Lesson Study cycle can be very important tools in developing skills of self-evaluation and reflection. One of the Home Economics teachers felt that it was "a highly effective way to self-reflect about different aspects of my teaching. I feel I have also begun to reflect more deeply about the learning of the pupils, and more specifically how they learn." Lesson Study can assist teachers in such reflective and critical problem solving by generating professional dialogue around issues of student learning and teaching methods, a process which P. Dudley argues results in "pedagogic solutions" (Dudley, 2008, 6).

Involving students in evaluating the lessons recognised them as important stakeholders who provided teachers with valuable feedback on the teaching methods used. As one teacher put it 'they made some excellent suggestions and their input was very valuable'. All of the teachers were of the view that Lesson Study focuses largely on the student experience and it is this characteristic that sets it apart from other methods of professional development. Arguably this is because the Lesson Study method is strongly grounded in classroom practice and the inclusion of the student perspective further enriched professional learning.

All of the teachers also favoured Lesson Study as a model of professional development over other models they had experienced: 'It is more valuable than subject workshops as it's based at ground level.' There was consensus among the teachers that active involvement in their own professional learning contributed to the success of this approach and this is reflected across the literature. For example, M. Dadds (1997) argues that top-down 'delivery model' initiatives are ineffective as the teacher is inactive in the process whilst A. Lauriala explains that in bottom-up approach teachers are "filters of innovations" (Lauriala, 2011, 17), and these innovations are successful if teachers understand and accept them. C. Day (1999) endorses the importance of the centrality of the teacher in decision making concerning the direction of their own professional learning and P. Dudley (2008) argues that there is mounting evidence of the increased use of teacher-teacher and school-school models of professional learning internationally. On the basis of the literature and the data in the project, it is reasonable to argue that Lesson Study contributed to professional learning in this study due to the grounded, collaborative and active approach involved and the generation of professional dialogue around real and complex issues of student learning and pedagogy. The value of self-evaluation and reflection-in-action was recognised as a way of broadening perspectives and understanding practice in depth, which in turn informed thinking and future decision making in relation to classroom practice.

\section{Lesson Study impact on classroom practice}

The impact of Lesson Study on the student outcomes in the project was not formally assessed through examinations, but the teachers expressed their professional opinions that the quality of learning improved as a result of the pedagogical approaches planned and implemented. One teacher, for example, was convinced "that pupil outcomes improved for the vast majority of those who were involved in this process". P. Dudley (2008) reported a similar finding from his Lesson Study pilot project, which was that students' views on learning changed and that they became overtly involved and engaged in the process of learning. "They see that learning is a process that they can have an impact on ... they begin 
to take ownership of the whole learning process ... they're engaging with us, in helping us to help them to learn" (Dudley, 2008, 6). As emphasised above, the involvement of students in this current research had enhanced teacher learning about practice:

'through focusing on the pupil voice, it has ensured that the evaluation of my teaching is much more worthwhile ... lesson observation is allowing us to focus more meaningfully on the engagement and learning of our pupils.'

The teachers that engaged in observation of their colleagues were able to see the lesson delivery at face value and they were also able to observe student learning. They reported learning from and being inspired by their colleagues within and across subject departments. One Home Economics teacher commented: 'I have had the opportunity to go into other teachers' classrooms and pick up new ideas and strategies. I feel this has made my teaching more varied and dynamic.' Another teacher reported that she had: 'developed excellent relationships with teachers who are not from within my subject area. I feel this has been hugely beneficial as I would not have had the opportunity to learn from their expertise without Lesson Study.' In this manner, many aspects of the Lesson Study project impacted positively on classroom practice and collegiality. Teachers variously reported improved quality of student learning, the benefits of the involvement of students in the Lesson Study feedback, experimentation with pedagogy in the lessons, the development of ideas from group deconstruction of the lessons and the creation of a platform for the sharing of ideas.

\section{A critique of the Lesson Study approach}

Conditions for good working relationships were established at the outset of the project by the participants and they felt that the key elements of the modus operandi of the process included trust, confidentiality, professionalism, respect, listening, taking risks, accountability, openness to improvement, constructive criticism and positive reinforcement. The project gathered momentum once the teachers developed a thorough understanding of the Lesson Study approach and could see the results beginning to manifest in practice. When positive results were experienced during the research lessons, teachers gained confidence in the use of the technique, for example: 'I feel we became more comfortable working together in the second round of lesson planning as we knew what to expect.'

One aspect of Lesson Study, classroom observation, has the potential to cause difficulty if colleagues view it in the same light as having their teaching performance evaluated: 'We thought it would be like being back on teaching practice by being observed.' S. Mitchell (Gardner et al., 2012) refers to the tension that existed in relation to classroom observation during a larger Lesson Study project in Northern Ireland schools, throwing light on the potential impact of teachers' previous teaching practice and inspection experiences on their views relating to classroom observation. On the one hand, 'some saw the project as a good opportunity for their own professional development and remembered the benefit of being evaluated and observed, recalling teaching practice and the chance to watch someone else as being "where you learn the most" (Gardner et al., 2012, 20). However, others had reservations about classroom observation as "since usually with observation people feel they're being judged" (Gardner et al., 2012, 20). There was consensus that with increasing familiarity, observation was viewed as less threatening: 'but as we got more into it, we soon realised that we all were accepting ownership of the lessons as we had planned them together and as a result we didn't feel nervous or inadequate.' They enjoyed it, despite at times being apprehensive about it, especially in the initial stages.

There was initial concern about the potential impact of classroom observation on students, for example that the process of observation could make them self-conscious and affect their performance. However, it was reported by all of the teachers that students benefited overall, especially as they were key participants in the research lessons.

Many of the teachers reported that the major obstacle to adopting the Lesson Study method was time: time for engaging with colleagues, trying out new ideas, planning, observing and debriefing:

'Time is an issue. Due to the demands of school life, observation feedback was not immediate after the actual lesson. Therefore, the lessons learned could not be implemented in my teaching in the lessons following the observed lesson.'

S. Mitchell reports the view of one head of department who "observed that in an ideal world there would be time to plan, explore and develop things" (Gardner et al., 2012, 19), but in reality, teachers can be 
burdened with assessments and paperwork that hinder their planning. She explains how some schools viewed the Lesson Study initiative as "the gift of time" (Gardner et al., 2012, 19) with the result that some teachers view it as a luxury competing against a lack of time for preparing resources, implementing and evaluating work to best effect. The Teaching Council of Ireland (Policy on the Continuum..., 2011) acknowledges the essential need for time and space to nurture the 'development of teachers as reflective, enquiry-oriented, life-long learners. This development is essential to prepare teachers to continually selfevaluate, collaborate and adapt throughout their careers in order that they might reflect the changing realities of the classrooms in which they will teach' (Policy on the Continuum..., 2011, 9). Time is a hugely important factor influencing practice and some researchers (Galanouli, Murphy, Gardner, 2004) argue that a lack of time for training can hinder professional development. D. Galanouli (2010) also notes that lack of time is a key cause of unwanted stress at work and recommends the factoring in of teacher cover in school budgets for those engaged in Lesson Study in order to allow time for planning, review meetings and the live observation of research lessons.

\section{Conclusions}

This research study sought to explore whether Lesson Study could improve classroom pedagogy through peer-to-peer collaboration in improving aspects of classroom practice. The data from the research roundly endorses the view that it can. A considerable improvement in aspects of the classroom practice under study was noted. In particular, Home Economics teachers' reflections on the Lesson Study approach provided evidence of collaborative professional learning, meaningful dialogue about pedagogy and student learning, and deeper levels of reflection on and in practice.

Opportunities were created to experiment with teaching approaches, resources and lesson planning and to share good practice. The teachers were actively engaged in action research in the classroom and the shared lessons promoted professional dialogue, inquiry-oriented conversations, self-evaluation and collective reflection. Lesson Study enabled a non-threatening, constructive and active peer-to-peer process of improving classroom teaching, which was firmly grounded in classroom practice. An important finding was that working across subject areas provided fresh insights to teachers about student learning in different contexts while using Lesson Study within the single subject area of Home Economics was found to be effective in achieving pedagogic improvements. There was consensus that the active involvement of students in their own learning and in the planning and evaluation of teaching methods and classroom activities enhanced the process of improving pedagogic practice. The live observation of research lessons was a revealing experience for teachers involved in the study as they were exposed to the dynamics of classroom practice in 'real time'. They were actively engaged as researchers and change agents by collecting and interpreting findings that informed their future thinking and decision making in relation to their own classroom practice. Authors offer the following summary of the reasons why they consider Lesson Study to be an effective method of professional development:

'It helps experienced teachers selectively to 'switch off' enough of the filters on their experience to see their teaching more clearly; because it enables teachers to learn something new about this teaching and their pupils; and because it helps teachers appreciate, through the eyes of their colleagues and the reflective process, the individual needs of all the children. Perhaps most importantly in these communities of practice, it makes teachers' practice visible to each other in the group, enabling them to create joint solutions to the enduring challenge 'how best to teach $\mathrm{x}$ better to $\mathrm{y}$ '.

All things considered, this research has demonstrated that Lesson Study is an effective professional development model, which has contributed to the development of two sets of teachers' pedagogical knowledge in two schools in Ireland. It combines reflective practice and systematic sharing in an organic context that radically contrasts with 'top-down' approaches to professional development. This project, based on two schools, may not offer a generalisable basis for concluding that Lesson Study will succeed as an effective school based professional development model, but the growing and consistent empirical base across the world highlighting its benefits certainly requires that it is given serious consideration by teaching councils, school managers and the Home Economics teaching profession. 


\section{Acknowledgements}

The authors are indebted to the teachers and students of the two schools involved for their positive and expert engagement with the project. We wish also to acknowledge the support of the Standing Conference on Teacher Education North and South (SCoTENS) and the General Teaching Council for Northern Ireland (GTCNI) without whose funding and facilitation the project would not have proceeded. The contributions of colleagues from St. Angela's, Dr. Mary Magee, and the GTCNI, Dr. Despina Galanouli and Gerry Devlin, were very much appreciated.

\section{Bibliography}

1. Brosnan A. (2007). The teaching of Mathematics at Post-Primary level in Ireland: A review of traditional patterns and an exploration of future. $\mathrm{PhD}$ thesis. Ireland: National University of Ireland Maynooth.

2. Burghes D., Robinson D. (2009). Lesson Study: Enhancing Mathematics Teaching and Learning. Guidance. Ireland: CfBT. Retrieved from http://webfronter.com/bexley/maths/menu2/Frontpage files/Subject Leaders/images/2LessonStudy v9 Web_.pdf

3. Cerbin W., Kopp B. (2006). Lesson Study as a Model for Building Pedagogical Knowledge and Improving Teaching. International Journal of Teaching and Learning in Higher Education, 18(3), 250-257.

4. Commission of the European Communities (2008). Improving competences for the 21st Century: An Agenda for European Cooperation on Schools. Brussels: Retrieved from http://eurlex.europa.eu/LexUriServ/LexUriServ.do?uri=COM:2008:0425:FIN:EN:PDF

5. Corcoran D. (2007). Put out into deep water and pay out your nets for a catch: lessons learned from a pilot study in Mathematics Lesson Study. In S.Close, D.Corcoran, T. Dooley (Eds.), Proceedings of Second Annual Conference on Research in Mathematics Education. Dublin: St. Patrick's College, 275-289.

6. Corcoran D., Pepperell S. (2011). Learning to Teach Mathematics Using Lesson Study. In T. Rowland, K. Rutheven (Eds.), Mathematical Knowledge in Teaching. London: Springer, 213-231.

7. Dadds M. (1997). Continuing professional development: nurturing the expert within. Journal of InService Education, 23(1), 31-38. Retrieved from http://www.tandfonline.com/doi/pdf/10.1080/13674589700200007

8. Day C. (1999). Developing Teachers: The Challenges of Lifelong Learning. London: Psychology Press.

9. Day C., Sachs J. (2004). Professionalism, performativity and empowerment: discourses in the politics, policies and purposes of continuing professional development. Maidenhead, UK: Open University Press.

10. DES (2010). Report of the Project Maths Implementation Support Group. Retrieved from https://www.education.ie/en/Publications/Policy-Reports/Report-of-the-Project-MathsImplementation-Group.pdf

11. Dudley P. (2008). Improving practice and progression through Lesson Study: Handbook for head teachers, leading teachers and subject leaders. Retrieved from

http://webarchive.nationalarchives.gov.uk/20110202093118/http:/nationalstrategies.standards.dcs f.gov.uk/node/132730

12. European Commission (2012). Education: Policy support for Teacher Educators' Conference Conclusions. Retrieved from

http://ec.europa.eu/education/events/2012/educator/conclusions_en.pdf

13. Fernandez C. (2002). Learning from Japanese approaches to professional development. The case of lesson study. Journal of Teacher Education, 53(5), 393-405.

14. Fernandez C., Yoshida M. (Eds.). (2004). Lesson Study: A Japanese Approach to Improving Mathematics Teaching and Learning. New York: Lawrence Erlbaum Associates.

15. Galanouli D. (2010). School-Based Professional Development. ( ${ }^{\text {st }}$ ed.). Belfast: General Teaching Council for Northen Ireland (GTCNI). Retrieved from http://www.gtcni.org.uk/publications/uploads/document/School-Based\%20comp_V3.pdf

16. Galanouli D., Murphy C.A., Gardner J. (2004). Teachers' perceptions of the effectiveness of ICT-competence training. Computers and Education, 43(1-2), 63-80.

17. Gardner J., Galanouli D., Devlin G., Magee M., Mc Sweeney K., McHenry M., McVeigh I., Mitchell S. (2012). Exploring Japanese Lesson Study as a Model of Peer-to-Peer Professional Learning. Standing Conference on Teacher Education, North and South (SCoTENS), 3-24. Retrieved from http://scotens.org/site/wp-content/uploads/Scotens-Report-FINAL-.pdf 
18. Kishi N., Arai N., Imot, R., Kamei Y., Hane Y., Isshiki R., Suzuki M., Kanzawa S. (2017). A study of Japanese lesson study in Home Economics. International Journal of Home Economics, 10(2), 86-98.

19. Lauriala A. (2011). Changes in teacher education and teacher action: connections to research paradigms and emerging teacher-as-a-researcher approach. Cork, Ireland: Teachers Council Conference. Retrieved from https://www.scribd.com/document/323726017/Anneli-Lauriala-Corkin

20. Leavy A.M., Hourigan M. (2016). Using lesson study to support knowledge development in initial teacher education: insights from early number classrooms. Teaching and Teacher Education, 57, 161-175.

21. Lewis C.C. (2009). What is the nature of knowledge development in lesson study? Educational Action Research, 17, 95-110.

22. Lewis C.C. (2010). A Public Proving Ground for Standards-Based Practice. Education Week. Retrieved from http://www.edweek.org/ew/articles/2010/09/15/03lewis.h30.html

23. Lewis C.C., Perry R., Murata A. (2006). How Should Research Contribute to Instructional Improvement? The Case of Lesson Study. Educational Researcher, 35(3), 3-14.

24. Ni Shuilleabhain A. (2016). Developing mathematics teachers' pedagogical content knowledge in lesson study: case study findings. International Journal for Lesson and Learning Studies, 5(3), 212-226.

25. Ni Shuilleabhain A., Clivaz S. (2017). Analyzing teacher learning in lesson study: mathematical knowledge for teaching and levels of teacher activity. Quandrante, 26/2, 99-125. Retrieved from https://www.academia.edu/35556398/Analyzing_teacher_learning_in_lesson_study_mathematica 1_knowledge_for_teaching_and_levels_of_teacher_activity

26. OECD (2009). Creating Effective Teaching and Learning Environments. First Results from TALIS, France: OECD publishing. Retrieved from http://www.oecd.org/education/school/43023606.pdf

27. OECD (2014). TALIS 2013 Results: An International Perspective on Teaching and Learning, TALIS. France: OECD publishing. Retrieved from https://www.mecd.gob.es/dctm/inee/internacional/talis2013/-talis-2014-eng--full-11ebook.pdf?documentId=0901e 72b819dbfd7

28. Policy on the Continuum of Teacher Education. (2011). Ireland: The Teaching Council. Retrieved from http://www.teachingcouncil.ie/en/Publications/Teacher-Education/Policy-on-theContinuum-of-Teacher-Education.pdf

29. Scheerens J. (Ed.). (2010). Teachers' Professional Development: Europe in international comparison. Luxembourg: Office for Official Publications of the European Union.

30. Stigler J.W., Hiebert J. (1999). The Teaching Gap: Best Ideas from the World's Teachers for Improving Education in the Classroom. New York: Free Press.

31. Teaching: The Reflective Profession. (2007). Belfast: General Teaching Council for Northen Ireland (GTCNI). Retrieved from

http://www.gtcni.org.uk/uploads/docs/gtcni_comp_bmrk\%20\%20aug\%2007.pdf 